\title{
Report from the conference "Application of the Succession Regulation in the EU Member States", Katowice 12 September 2019
}

Remarkable events do occur sparsely and usually do not last long. Yet, they have the unique ability of profoundly marking the people involved by leaving a lasting memory of the days long gone and serve as a source of inspiration for the future endeavors in the days to come.

On 12 September 2019, the premises of the Faculty of Law and Administration of the University of Silesia in Katowice (Poland) witnessed one of such events, which will arguably go down in history of private international law in Poland. On that day, the University hosted an international conference on the Regulation (EU) No 650/2012 of 4 July 2012 on jurisdiction, applicable law, recognition and enforcement of decisions and acceptance and enforcement of authentic instruments in matters of succession and on the creation of a European Certificate of Succession ("the Succession Regulation"), and on the various issues relating to the succession matters within the European area of freedom, security and justice.

The conference was organized at the occasion of the annual session of the European Group for Private International Law (EGPIL/GEDIP) held at the premises of the Faculty at the invitation of Maciej Szpunar,

\footnotetext{
a) Dr, Legal clerk at the Court of Justice of the European Union.
} 
a member of the Group, Professor at the University of Silesia and First Advocate General at the Court of Justice of the European Union.

Opening the conference, Maciej Szpunar, Tomasz Pietrzykowski, Professor at the University of Silesia and Vice-rector for National and International Cooperation, and Piotr Pinior, Professor at the University of Silesia and Vice-dean for Scientific Affairs, addressed their word of welcome to all the participants, invited guests and staff of the Faculty. Acknowledging the efforts made by the speakers coming from various jurisdictions, they expressed their gratitude for their presence in Katowice. They emphasized the importance of the event for the entire Polish academic community, not omitting to note that such unique gathering of prominent experts constitutes an unusual phenomenon even on the European scale. Special words of gratitude were addressed to the bodies and organizations which have supported the organization of the conference, namely the Polish National Council of Notaries (Krajowa Rada Notarialna), National Chamber of Legal Advisers (Krajowa Izba Radców Prawnych), Supreme Bar Council (Naczelna Rada Adwokacka) and Association of the Notaries of the Republic of Poland (Stowarzyszenie Notariuszy RP).

Before giving the floor to the speakers, Maciej Szpunar, Tomasz Pietrzykowski and Piotr Pinior wished everyone fruitful deliberations and hoped for their enjoyable stay in Poland.

1.

The opening session of the conference was devoted to the review of the Member States' first experiences with the application of the Succession Regulation. Four speakers were invited to present their lectures on that very topic.

In his lecture opening that session, Andrea Bonomi, University of Lausanne, Director of its Centre of Comparative, European and International Law and co-director of LL.M. International Business Law, addressed the interplay between the Succession Regulation and the new Regulations on Matrimonial Property and Registered Partnership.

Professor Bonomi built his subsequent considerations on the observation that the Succession Regulation, on the one hand, and the twin Regulations on Matrimonial Property and on Registered Partnership, on the other hand, will often be applied in parallel due to the close connection between the areas they govern. As he remarked, not all Member States participate in the enhanced cooperation regarding the matrimonial pro- 
perty and registered partnership. A certain legal duality thus persists within the EU. He continued by explaining that, from the perspective of the Member States bound by these Regulations, some of their provisions (the rules on jurisdiction and on conflict of laws) do however apply in relation to the situations linked with third States as well as with the Member States that do not participate in the enhanced cooperation relating to the areas that these Regulations govern.

After having discussed the recent case law and the judgment in Mahnkopf in particular, Professor Bonomi noted that the CJEU had pronounced itself in favour of a broad definition of the notion of "succession", which delineates the scope of application of the Succession Regulation. Referring the considerations relating to the effectiveness (effet utile) of the Regulation that resonate within the AG's Opinion in the Mahnkopf case, he reflected then on the implications of such broad and effectiveness-oriented definition of that notion on the scope of application of the Matrimonial Property Regulation and the effectiveness thereof.

He concluded his lecture by comparing the solutions achieved by the parallel application of the Succession and Matrimonial Property Regulation with those that can be attained by the application of the former Regulation and the national conflict of laws rules.

Afterwards, Christian Kohler, Saarland University, discussed the application of the Succession Regulation by German courts. It is worth noticing that, as of 12 September 2019, the CJEU rendered five judgments in the cases relating to the Succession Regulation, namely in the cases Kubicka, Mahnkopf, Oberle, Brisch and WB. As Professor Kohler observed, the German courts had contributed to the development of the case law, by having been actively engaged in the dialogue with the CJEU by the means of the preliminary reference procedure. This case law had then major implications for Germany.

Against this background, Professor Kohler addressed, inter alia, the judgment in Mahnkopf. Echoing the previous lecture, he added that the solution endorsed in the AG's Opinion and adopted by the CJEU indeed preserves the effet utile of the European Certificate of Succession. However, while it has the potential of facilitating the Regulation's application, it does not the eliminate the controversy resulting from the interfaces between 'inheritance law' and 'property law', it - as the Professor graphically put it - merely reverses these two tags.

By his lecture, Professor Kohler then went on to illustrate that the aforementioned case law of the CJEU forms only a tip of the iceberg that had been built upon the Succession Regulation. He briefed the participants on the developments of German courts relating to, inter alia, the determination of the habitual residence of the deceased. 
Finally, Maksymilian Pazdan, Koźmiński University and University of Silesia, and Maciej Zachariasiewicz, Koźmiński University, delivered a detailed assessment of the Succession Regulation's highlights and pitfalls.

While the Professors deemed the Regulation to be a true milestone, they did not omit to acknowledge the decisive role that the EGPIL/GEDIP had played in shaping the conflict-of-laws landscape prior to the adoption of that Regulation. The particularly profound words of consideration were addressed to another speaker, Professor Paul Lagarde. If the Regulation is truly a milestone, it rests on the foundations meticulously laid by the Professor and his scientific achievements. Suffice is to mention the comparative rapport of 2002 on the rules of jurisdiction and rules on conflict of laws, prepared by the German Notarial Institute, in cooperation with Professor Heinrich Dörner and the very Professor Paul Lagarde.

Sharing their expert knowledge, Maksymilian Pazdan and Maciej Zachariasiewicz observed that the recourse of the Polish notaries to the Succession Regulation had been gradually more frequent. They noted that much credit for dissemination of knowledge on the Regulation must be given to organizations of notaries. Indeed, the presence of the National Council of Notaries and of the Association of the Notaries of the Republic of Poland among the bodies supporting the organization of the conference served as a confirmation of the observation made by the Professors.

In their presentation, the Professors spoke mostly highly of the Succession Regulation, praising, inter alia, the unitary approach that the Regulation takes regarding the law applicable to succession and the inclusion of the rules on jurisdiction and on the conflict of laws in a single EU law instrument (leaving aside the Insolvency Regulation, as of 2012 when the Succession Regulation had been adopted, it had still been an uncommon practice in the EU private international law).

Complementing the illustration of German case law on the determination of the habitual residence of the deceased provided by Christian Kohler, they reflected on the admissibility of multiple places of habitual residence under the Succession Regulation.

After the opening session and a short break - which, basing on the vigorous discussions between the participants that continued after the session's closure, illustrated the fact that the lectures had indeed touched upon issues that inspire much debate - the subsequent segments of the event followed. 
Once the resumption of deliberations took place, Paulina Twardoch, University of Silesia, delved into the issue of marriage contracts in the context of the Succession Regulation.

Referring to her publication on that very issue (P. Twardoch, Umowy małżeńskie w prawie prywatnym międzynarodowym, Warszawa 2019), Professor Twardoch observed that the spectrum of matters that may be regulated in a marriage contract varies considerably. One might therefore be dealing with a marriage contract which - from the conflict of laws perspective - is segmented into parts falling within such categories as "matrimonial property regime", "maintenance obligation" or even "divorce and legal separation".

She continued by presenting a rich palette of clauses that may be, according to various legal systems, introduced in a marriage contract (in a marital or premarital agreement) and by providing guidance on their classification under the relevant rules on conflict of laws.

She explained that the clause-segments that boil down to a donation of future property constitute "agreements as to the succession" within the meaning of the Succession Regulation. As such, they are governed by the law determined as applicable under Article 25 of the Regulation.

On the contrary, by reading a contrario the guidelines provided for in the judgment in Mahnkopf, she argued that the clauses that provide property advantages for the surviving spouse by virtue of a matrimonial property regime [the preciput clause, the clause providing for an unequal division of the community of property, the clause of unequal participation in the surplus (le bénefice), modifying the Swiss statutory matrimonial property regime etc.] cannot be considered as "agreements as to the succession".

However, the clauses by which a (future) spouse or both (future) spouses waive the right of elective share (such clause is admissible under, among others, the law of the NY State), should be qualified as the "agreements as to succession". The same applies to the so-called "pacte Valkeniers", that is to say the clauses falling within the scope of Article 1388(2) of the Belgian Civil Code and consisting on a total or partial waiver of the statutory succession rights of the surviving spouse. Finally, though not all authors would share this view according to Professor Twardoch, this is also the case of the stipulations of a premarital or marital agreement that constitute a contract to make or not to make a will. 
3.

Subsequently, Andrea Bonomi, speaker of the opening session, took the presidency over the first panel discussion headed "Delimitation between succession law and other applicable laws" and invited the panelists to share their remarks on that topic.

Stefania Bariatti, University of Milan, was first to take the speech in the panel and presented her remarks on the issue of preliminary question in the context of succession with cross-border implications ("The Capacity and the Quality of a Heir. Possible Interaction with Preliminary Questions").

Professor Bariatti observed at the outset that a number of issues that may be relevant in this context is excluded from the scope of the Succession Regulation. Some of these issues are also explicitly excluded from the scope of other instruments of EU private international law. These instruments provide nearly unanimously that the "the status of natural persons" and/or "family relationships and relationships deemed by the law applicable to such relationships to have comparable effects" do not fall within their scope of application. In some, the EU legislator goes as far as to state - as in Article 1(2) of the Rome III Regulation - that these issues are excluded "even if they arise merely as a preliminary question within the context of divorce or legal separation proceedings".

The EU legislator acknowledges therefore the existence of preliminary questions, yet no clear guidance on the law applicable to these questions is given.

Filling this gap, Professor Bariatti drew a distinction between "independent reference" (a preliminary question governed by the law determined as applicable under the rules on conflict of laws of the forum that are relevant to the object of the preliminary question at stake) and "dependent reference" (a preliminary question should be governed by the same law that applies to the main question, lex causae, including the rules on conflict of laws provided for in that law) and demonstrated which of these concepts should be adopted in relation to the preliminary questions on "personal status", "family relationship" and "legal capacity".

Next, Tomasz Kot, Vice President of the Polish National Council of Notaries, presented his remarks concerning the puzzling issues of the scope of application of the Succession Regulation and the scope of the law applicable to the succession ("Where is a Borderline of Succession Law? A Dilemma of European Notaries Dealing with the Succession Regulation”). 
Backing his remarks with practical knowledge, he presented the issue as it is seen from the perspective of notaries who are in the frontline of the Regulation's application. This valuable view "from the trenches" was a true testimony of the issues that the practitioners may encounter, despite the efforts of EU legislator to address many of them. The insights on the issues surfacing in the scenarios relating to the international successions linked both to Poland and to Germany were particularly illustrative in these regards.

These insights were followed by the remarks of Paul Lagarde, Professor emeritus at the University of Paris 1 - Panthéon-Sorbonne, on the reserved share (réserve héréditaire) ("La réserve héréditaire dans le règlement 650/2012 sur les successions" / "Reserved Share under the Succession Regulation").

Under French law, as reminded by Professor Lagarde, certain relatives are entitled to the reserved share. Providing a comparative insight, he noted that while the French legal system is generous in these regards, some legal systems adopt intermediate solutions that are less lavish and others (i.e. common law systems with the notable examples of the United Kingdom and some US States) go so far as to deny the reserved share - in these legal systems, the family members and dependents have to bring a claim for financial support before courts and that support is being then deducted from the estate.

The diversity of solutions concerning the reserved share raises numerous questions in the cross-border scenarios. The issue of applicable law is among them and Professor Lagarde did acknowledge the EU legislator's efforts to address them in the Succession Regulation. He noted that by abandoning both the nationality as the connecting factor, a sort of tradition under Polish law, as well as the principle of scission, which had been a tradition in French law, the Succession Regulation submits in principle the succession to the law of the State in which the deceased had his habitual residence at the time of death (Article 21). Moreover, the Regulation provides an important clarification regarding the reserved share and includes it in the scope of law governing the succession [Article 23(2)(h)].

Still, not all the issues had been resolved. Professor Lagarde explained that these issues result less from the wording of the Succession Regulation and more from the existence, among the Member States, of the aforementioned diversity when it comes to their approach to the reserved share.

Professor Lagarde illustrated the issues in question by two cases that had recently attracted much attention in France.

First reported case concerned the succession of the French singer John Hallyday, who had passed away in 2017. He left a will bequeathing 
his entire estate to his wife, whilst leaving nothing to his children from his previous relationships. As observed by Professor Lagarde, the issue at stake ultimately had boiled down the question whether the deceased had had his last habitual residence in France or California. The habitual residence of the deceased would then determine the law applicable to the succession. If the law of the State of California applied, the question remained whether its application did not stand in violation of to the French international public policy.

The second case reported by Professor Lagarde concerned the succession of yet another iconic French artist, Maurice Jarre, who had passed away in 2009. Prior to his death, the artist disinherited his children for the benefit of his wife. Here, there was no controversy concerning the habitual residence of the deceased - it had been acknowledged that the law of the State of California governed the succession. However, his children argued that, by not providing for the reserved share, the law of the State of California violated the French international public policy. By its judgment of 2017, the French Supreme Court (Cour de Cassation) proved them wrong. It ruled that a foreign law that does not provide for the reserved share is not in itself contrary to the French international public policy and that it can only be set aside if its concrete application, in the case at hand, leads to a situation that is incompatible with the principles of French law considered as essential.

Professor Lagarde praised the solution as it adequately reflects the spirit of the public policy exception, which relies on in casu examination of the circumstances of the case. He explained that before setting aside the application of foreign law, it is necessary to examine, on a case-bycase basis, whether its application leads to an unacceptable situation, for example by leaving young children or children undergoing education with no resources.

Nonetheless, Professor Lagarde remarked that the case has by no means reached its end. In 2018, the children of Maurice Jarre brought their case before the European Court of Human Rights arguing the failure to respect the rights of the family and excessive infringement of their legal security.

He then went on to report on the recent developments in Monaco, where - during the elaboration of the new code on private international law - it had been initially proposed to follow the solutions somewhat similar to these of the Succession Regulation. However, Article 63 of the Code on Private International Law of 2019 provides ultimately in its second paragraph that "the law applicable to the succession may not have the effect of depriving an heir of the reserved share to which he or she is entitled under the law of the State of which the deceased was a national 
at the time of his death, nor of imposing the reserved share where the law of the State of which the deceased was a national at the time of his or her death does not provide for such a regime".

Professor Lagarde remarked that the desire to impose on a Monegasque national, in the name of public policy of that State, the provisions of its law on the reserved share might be understandable. However, he deemed it more difficult to accept that the application of the Monegasque law to the succession of an Englishman domiciled in Monaco violates its public policy. He argued that second paragraph of Article 63 of the Code undermines the principle of the unity of succession and removes the reserved share from the scope of law applicable to succession by submitting it to the law of the nationality of the deceased. Concluding his remarks, Professor Lagarde observed that also under the Succession Regulation, the recourse to the public policy exception should by no means serve as a vehicle for disapplication of the provisions that offer lesser protection than the law of the nationality.

Closing up the panel discussion on the delimitation of the applicable laws, Krzysztof Pacula, Legal clerk at the CJEU and a PhD in private international law, presented his remarks relating to the unitary approach to succession that underlies the system of Succession Regulation ("The Principle of a Single Estate and Its Role in Delimiting the Applicable Laws"). In his view, it also sets a tone for some interpretative techniques that tend to favor succession-related characterization of the issues having certain importance in the context of international succession (i.e. effet utile utile-driven characterization).

The president of the panel, Andrea Bonomi, encouraged then the participants to present their feedback and inquiries in relation to the remarks presented within the panel.

Among other inquiries, Paul Lagarde was invited to present his insights regarding the national provisions in force in the States that do not provide for a reserved share as it exists under French law. In these States (i.e. Poland), the freedom of the testator to dispose his estate is not restricted, yet closest members of the family have monetary claims corresponding to a certain portion of the estate's value. In particular, Professor Lagarde was asked whether these national provisions could be of a certain importance in the context of public policy exception and/or overriding mandatory provisions. He was also requested to elaborate on the scope of the law applicable to the succession and Article 1002 of the Polish Civil Code, which provides that a monetary claim of an heir passes upon his (her) only if the latter is also ab initio entitled to bring his (her) own monetary claim. 
In turn, Tomasz Kot was encouraged to share more of his experiences on the practical implications of the Succession Regulation applicability for the notaries in Poland.

The lively debate seemed to remain unaffected by a short pause that followed, as the participants continued to engage into discussions until the conference deliberations were resumed.

\section{4.}

The second panel has been presided by Cristina González Beilfuss, University of Barcelona. Professor González Beilfuss invited the panelists to present their remarks in the discussion devoted to the issue of "Jurisdiction and the free movement of judgments and other instruments covered by the Succession Regulation".

Jürgen Basedow, University of Hamburg, Director emeritus of the Max Planck Institute of Comparative and International Private Law, was first to take the speech in the subsequent panel. Elaborating on the notion of "Member State" ("The term 'Member State' within the meaning of Article 39 of the Succession Regulation"), Professor Basedow explained that within the framework of the Succession Regulation three different categories of States may be distinguished: participating Member States, non-participating Member States and third States. He then put under scrutiny the dichotomous distinction (participating Member States/non-participating States), based on the assumption that the notion of "Member State" must be interpreted in a uniform way throughout the Succession Regulation. In disagreement with that view, he argued that this notion has to be interpreted accordingly to the context and the purpose of each individual provision.

Marcin Margonski, Dr. iur., presented then his insights on the issues residing on the highly practical side of the Succession Regulation's application ("Recording heirs with European Certificate of Succession, court decisions or authentic documents from other Member States in national property registers"). Setting the tone for his intervention, he observed at the outset that the issues relating to such recording are one of the main reasons explaining why the international regulation concerning succession is unpopular and mostly avoided at least by some States.

As to the Succession Regulation itself, he explained that the Member States' obligation to accept a European Certificate of Succession as a reg- 
istration basis results directly from Article 65(5) of the Regulation. Providing a comparative insight, he noted that in some legal systems there had been no amendments concerning the acceptance of the Certificate as a registration basis (i.e. Poland), while in others the amendments for such effect had been made (Germany, Austria, the Netherlands).

Touching upon the "decisions" within the meaning of the Succession Regulation, he remarked that Article 39 does not contain a provision comparable to that of Article 65(5) of the Regulation. Such provision providing a registration basis as to the decision had not been necessary. As he observed, prior to the adoption of the Regulation, there had been no controversy as to the acceptance of decisions as the registration basis.

He then went to report on "authentic instruments" and noted that "acceptance" of these instruments provided for in Article 59 of the Succession Regulation is an entirely new concept that calls for CJEU guidance (i.e. in order to adequately address the registration of Polish notarial and/or court certificates by the German register offices).

Next, Piotr Rylski, University of Warsaw, delved into the analysis of Article 75 of the Succession Regulation and its implications with regards to the Members States having concluded bilateral agreements with third States ("The Influence of Bilateral Treaties with Third States on Jurisdiction and Recognition of Decisions in Matters of Succession - Polish Perspective").

Professor Rylski noted that from the Polish perspective, this analysis is of a particular practical importance due to the bilateral agreements concluded between Poland and Belarus, Russia and Ukraine and taking into account the migration of population between the parties to these agreements. He observed that the particularity of these agreements resides in the fact that they do not solely contain rules on conflict of laws but also rules on (direct) jurisdiction in matters of succession. Next, still reporting on the aforementioned agreements, he noted that they do not contain a provision providing for a public policy exception as a ground for non-recognition of the decisions issued in the parties to these agreements. He then went to address the question whether and, if so, how such exception could be introduced within the framework of the cooperation between these parties. In a similar vein, he addressed the question whether a European Certificate of Succession can be issued with regards to a succession falling within the scope of a bilateral agreement.

Following the clarifications of Jürgen Basedow on the notion of "Member State" within the meaning of the Succession Regulation, Michael Wilderspin, European Commission, presented his remarks on the notion of "court" in the sense of the Regulation ("Interpretation of a term 'court' in the Regulation and its consequences for the rules concerning 
jurisdiction"). He too advocated a meticulous analysis of the notion in question. While the notion of "court" gave rise to a case law clarifying this notion under the Brussels regime, he deemed it not to be perfectly transposable to the Succession Regulation.

5.

As all the good things tend to do, ultimately the conference also had to reach its end. Closing the conference, Maciej Szpunar congratulated the participants for having addressed numerous issues of a paramount theoretical and practical importance and thanked them for their meaningful contribution in the discussion on the EU private international law. On the behalf of the conference organizers, he expressed the gratitude for allowing the Faculty of Law of Administration of University of Silesia to go down in history as the place where that contribution had been made.

The discussions initiated during the day lasted in a more cameral atmosphere long after the closure of the conference. Yet, the days to come were still about to bring more exciting and remarkable events that are presented in other contributions contained in this volume of "Problemy Prawa Prywatnego Międzynarodowego". 